\title{
PELATIHAN PEMBUATAN MEDIA PEMBELAJARAN IPA BERBASIS LINGKUNGAN BAGI GURU-GURU MI KABUPATEN BULELENG
}

\author{
Dewi Oktofa Rahmawati 1,*, A.A.I. Agung Sudiatmika ${ }^{2}$, Putu Budiasa ${ }^{3}$ \\ 1 Jurusan Pendidikan Fisika. Universitas Pendidikan Ganesha, Indonesia \\ 2 Jurusan Pendidikan Fisika. Universitas Pendidikan Ganesha, Indonesia \\ 3 Jurusan Pendidikan Fisika. Universitas Pendidikan Ganesha, Indonesia
}

\begin{abstract}
Abstrak
Tujuan pengabdian ini adalah melatih guru-guru Madrasah Ibtidaiyah (MI) Kabupaten Buleleng membuat media pembelajaran IPA berbasis lingkungan. Metode kegiatan ini menggunakan sistem pelatihan. Sasaran pengabdian adalah guru-guru IPA Madrasah Ibtidaiyah (MI) Negeri dan Swasta yang ada di Kabupaten Buleleng berjumlah 34 orang. Data media pembelajaran IPA berbasis lingkungan yang dibuat guru-guru MI dan aktivitas guru dikumpulkan melalui teknik observasi, data respon guru terhadap pelaksanaan kegiatan pelatihan dikumpulkan dengan angket. Data tersebut dianalisis secara deskriptif. Hasil pelaksanaan program kegiatan ini menunjukkan Skor ratarata media pembelajaran IPA berbasis lingkungan yang dihasilkan guru-guru MI adalah 83,7 berkategori baik dengan standar deviasi 1,81. Aktivitas guru-guru MI pada kegiatan pembuatan media pembelajaran berkategori sangat tinggi, dengan skor rata-rata 85,4 dengan standar deviasi 0,96. Respon guru peserta pelatihan terhadap pelaksanaan kegiatan pelatihan sangat positif.
\end{abstract}

Keywords:

media pembelajaran

\section{Pendahuluan}

Kompetensi pedagogik salah satu kompetensi yang harus dikuasai seorang pendidik (guru) selain kompetensi kepribadian, propesional, dan sosial. Kompetensi pedagogik menuntut seorang guru mampu mengelola pembelajaran yang meliputi pemahaman peserta didik, perancangan dan pelaksanaan pembelajaran, evaluasi hasil belajar, dan pengembangan peserta didik untuk mengaktualisasikan berbagai potensi yang dimilikinya sehinggga pembelajaran menjadi bermakna (Dirjen Dikti, 2005). Pembelajaran yang bermakna adalah pembelajaran yang memberikan pengalaman belajar pada peserta didik. Pengalaman belajar yang beragam dapat diciptakan guru pada semua pembelajaran tidak terkecuali pembelajaran IPA SD/MI. Hal ini selaras dengan hakekat dan tujuan pembelajaran IPA SD/MI. Hakikat IPA meliputi empat unsur utama yaitu: sikap, proses, produk, dan aplikasi. Sedangkan tujuan pembelajaran IPA di SD/MI adalah agar siswa memiliki kemampuan mengembangkan pengetahuan dan pemahaman konsep-konsep IPA yang bermanfaat dan dapat diterapkan dalam kehidupan sehari-hari, mengembangkan rasa ingin tahu, sikap positif, dan kesadaran tentang adanya hubungan yang saling mempengaruhi anata IPA, lingkungan dan teknologi, dan mengembangkan keterampilan proses untuk menyelidiki alam sekitarnya dan memecahkan masalah. Oleh karena itu, pembelajaran IPA SD/MI hendaknya menekankan pada pengalaman langsung untuk mengembangkan kompetensi agar peserta didik mampu memahami alam sekitar melalui proses mencari tahu dan berbuat.

Pembelajaran IPA SD/MI yang menekankan pada pemberian pengalaman belajar secara langsung melalui penggunaan dan pengembangan keterampilan proses dan sikap ilmiah memerlukan kompetensi guru IPA yang mampu menyiapkan dan menggunakan berbagai media pembelajaran. Media pembelajaran dapat membantu guru memperjelas materi pelajaran yang disampaikan kepada siswa dan mencegah terjadinya verbalisme pada diri siswa. Sebab, pembelajaran yang mengggunakan banyak verbalisme tentu akan membosankan. Sebaliknya pembelajaran akan lebih menarik, bila siswa merasa senang dan gembira setiap menerima pelajaran dari gurunya. Kehadiran media dalam pembelajaran IPA SD/MI sangat diperlukan karena perkembangan mental atau kognitif anak pada usia $7-11$ atau 12 tahun berada tahapan operasional kongkrit. Hamalik (1986) mengemukakan bahwa pemakaian media pengajaran dalam proses belajar mengajar dapat membangkitkan keinginan dan minat yang baru, 
membangkitkan motivasi dan rangsangan kegiatan belajar, dan bahkan membawa pengaruh-pengaruh psikologis terhadap siswa.

Penggunaan media pembelajaran di dalam proses belajar mengajar dapat memperjelas penyajian pesan dan informasi sehingga dapat memperlancar dan meningkatkan proses dan hasil belajar, dapat memberikan kesamaan pengalaman kepada siswa serta memungkinkan terjadinya interaksi langsung dengan guru, masyarakat, maupun lingkungan. Penyampaian materi pelajaran dapat diseragamkan dengan menggunakan media pembelajaran. Proses pembelajaran menjadi lebih interaktif, jelas dan menarik, serta efisiensi dalam waktu dan tenaga.

Media Pembelajaran banyak sekali jenis dan macamnya. Mulai yang paling kecil, sederhana dan murah hingga media yang canggih dan mahal harganya. Ada media yang dapat dibuat oleh guru sendiri, ada media yang diproduksi pabrik. Ada media yang sudah tersedia di lingkungan yang langsung dapat kita manfaatkan, ada pula media yang secara khusus sengaja dirancang untuk keperluan pembelajaran.

Hasil wawancara yang dilakukan pada guru-guru IPA pada beberapa sekolah MI bahwa pada pelaksanaan kegiatan pembelajaran guru monoton menggunakan media papan tulis, pembelajaran cendrung bersifat verbal dan kurang inovatif. Guru yang cendrung menggunakan media papan tulis yang monoton dan pembelajaran cendrung bersifat verbal dan kurang inovatif berdampak pada lemahnya penguasaan konsep-konsep IPA yang diperoleh siswa. Hal ini i tercermin dari perolehan nilai ujian akhir nasional, untuk mata pelajaran IPA tidak pernah mencapai rata-rata lebih dari 6,0.

Media pembelajaran IPA adalah sesuatu yang digunakan guru yang bersifat menyampaikan pesan/informasi untuk merangsang pikiran, perasaan, dan kemampuan siswa sehingga mendorong terjadinya proses belajar pada dirinya. Mengingat perkembangan mental atau kognitif anak pada usia 7 11 atau 12 tahun berada tahapan operasional kongkrit maka penggunaan media sangat diperlukan untuk menunjukan konsep-konsep atau prinsip-prinsip IPA agar tidak bersifat abstrak. Media pembelajaran IPA juga memberikan pengalaman belajar yang sama pada seluruh siswa. Media pembelajaran IPA SD/MI yang digunakan dalam pembelajaran tidak harus bagus dan mahal. Media pembelajaran IPA SD/MI dapat dibuat dari bahan yang ada di sekitar lingkungan kita, Diperlukan kemauan yang kuat dari guru dan didukung oleh pengetahuan, pemahaman konsep-konsep IPA yang relevan dan keterampilan merancang dan membuat media pembelajaran IPA berbasis lingkungan.

Kemampuan guru IPA pada sekolah MI dalam merancang dan membuat media pembelajaran IPA berbasis lingkungan sangat rendah. Hasil wawancara dari beberapa guru sekolah MI yang ada dikota Singaraja menyatakan bahwa guru tidak memiliki gambaran media pembelajaran yang dapat dibuat dari bahan lingkungan/ bahan recycle untuk menyampaikan konsep-konsep IPA. Hal ini didukung oleh hasil observasi pada proses pembelajaran, guru hanya menggunakan media pembelajaran papan tulis. Bahkan sekolah MI yang telah memiliki KIT IPA, gurunya juga mengajar masih menggunakan media papan tulis dengan metode ceramah. KIT IPA yang ada disekolah jarang disentuh dengan alasan tidak ada panduan penggunaan alat. sehingga takut rusak.

Tidak semua sekolah MI memiliki KIT IPA yang dapat digunakan guru sebagai media pembelajaran. Hanya 5 sekolah MI Negeri yaitu MIN Singaraja, Tegallinggah, Patas Gerokgak dan Gondol memiliki KIT IPA, namun dengan jumlah yang terbatas (1- 2 buah). Tidak semua konsep -konsep IPA (fisika) yaitu wujud benda, sifat benda dan kegunaannya, gaya, energi panas dan bunyi, energi alternatif, teknologi sederhana, cahaya dan sifat-sifatnya, energi dan perubahannya, pesawat sederhana, listrik dan magnet yang merupakan ruang lingkup pembelajaran IPA kelas 4, 5 dan 6 dapat diisampaikan dengan KIT IPA yang ada disekolah. Diperlukan kemampuan guru dalam merancang dan membuat media pembelajaran. Media pembelajaran yang harus dimiliki SD/MI tidak harus mahal dan mewah. Media pembelajaran dapat dibuat dari bahan-bahan yang ada di lingkungan sekitar kita atau dari bahan recycle tanpa menghilangkan hakekat dan tujuan media pembelajaran tersebut.

Pemahaman konsep IPA guru sekolah MI yang relevan dengan media pembelajaran IPA tergolong rendah. Hal ini terungkap dari data guru IPA pada sekolah MI adalah sarjana S1 lulusan pendidikan Agama Islam (PAI), S1 Teknik komputer, dan S1 Bahasa Indonesia . dan S1 Matematika Banyak masalah masalah pembelajaran ditemui dan perlu ditangani di 17 MI yang terdiri dari 5 sekolah MI Negeri dan 12 sekolah MI Swasta yang tersebar di Gondol, Patas, Gerogak, Tegallinggah, Pegayaman, Kaliasem, Pengastulan, Seririt, Celukan Bawang, Sumber Kima, Sangga Langit dan Singaraja. Pengetahuan guru-guru IPA tentang peran media pembelajaran, model-model/ pendekatan/strategi pembelajaran yang inovatif serta pemahaman konsep-konsep yang terkandung pada materi IPA tidak memadai, sehingga prosses pembelajaran bersifat monoton dan bersifat verbal. Siswa menjadi cepat bosan dan konsep-konsep yang disampaikan sulit diterima atau dipahami siswa. Proses pembelajaran IPA di sekolah MI tidak

berjalan sesuai dengan tuntutan kurikulum 13 yaitu pembelajaran yang menciptakan 5M (menanya, mengamati, mencoba, mengasosiasi dan mengkomunikasi) pada diri siswa. 
Tidak tersentuhnya sekolah-sekolah MI pada kegiatan-kegiatan pelatihan, seminar workshop tentang model-model/pendekatan/strategi/teknik pembelajaran, penyegaran materi IPA SD, pembuatan media pembelajaran atau lainnya berdampak pula pada profesionalisme guru.

Hasil analisis situasi dan permasalahan yang dialami guru-guru IPA sekolah MI Negeri dan Swasta di Kabupaten Buleleng terletak pada kesulitan guru-guru membuat media pembelajaran IPA berbasis lingkungan yang bersifat menyampaikan pesan/informasi untuk merangsang pikiran, perasaan, dan kemampuan siswa sehingga mendorong terjadinya proses belajar pada dirinya. Kemampuan guru membuat media pembelajaran IPA berbasis lingkungan yang relevan dengan konsep yang disampaikan masih rendah.

Berdasarkan uraian diatas tujuan pengabdian ini adalah untuk melatih guru-guru IPA sekolah MI Negeri dan Swasta di Kabupaten Buleleng membuat media pembelajaranan IPA berbasis lingkungan yang relevan dengan konsep yang disampaikan guna menunjang pembelajaran IPA.

\section{Metode}

Metode pelaksanaan kegiatan pengabdian kepada masyarakat ini dilakukankan untuk mengatasi masalah yang dihadapi oleh guru IPA sekolah MI Negeri dan Swasta di Kabupaten Buleleng dalam bentuk kegiatan pelatihan. Tujuan kegiatan ini untuk membekali guru-guru IPA sekolah MI merancang dan membuat media pembelajaran IPA berbasis lingkungan yang relevan dengan konsep yang disampaikan. Susunan kegiatan sebagai berikut: 1) Kegiatan pelatihan ini didahului dengan penyampaian materi peran media dalam pembelajaran, dilanjutkan dengan penyegaran materi IPA SD/MI (fisika) dan diskusi. 2) Identifikasi bahan-bahan lingkungan atau bahan recycle yang dapat digunakan untuk membuat media pembelajaran IPA berbasis lingkungan yang relevan dengan konsep yang sampaikan oleh peserta pelatihan. 3) Latihan pembuatan media pembelajaran IPA berbasis lingkungan dipandu oleh Nara sumber. Penilaian proses berupa aktivitas peserta pelatihan yaitu kehadiran peserta pelatihan dan aktivitas pembuatan media pembelajaran IPA berbasis lingkungan. 4) Dilanjutkan secara mandiri membuat media pembelajaran IPA berbasis lingkungan. 5) Presentasi produk media pembelajaran IPA berbasis lingkungan. 5) Para pendamping memfasilitasi diskusi dan kegiatan selama pelatihan untuk memperlancar jalannya pelatihan.

Data data media pembelajaran IPA berbasis lingkungan sebagai produk pelatihan, data aktivitas guru saat membuat media pembelajaran IPA berbasis lingkungan dikumpulkan melalui teknik observasi dan data respon peserta pelatihan terhadap kegiatan pelatihan ini dikumpulkan melalui angket kemudian dianalisis secara deskriptif. Adapun indikator produk media pembelajaran IPA berbasis lingkungan adalah 1) media pembelajaran menyampaikan pesan pembelajaran yang relevan, 2) media pembelajaran sederhana, mudah di buat dan inovatif sedangkan indikator aktivitas guru peserta pelatihan adalah 1) mengidentifikasi bahan lingkungan sebagai bahan pembuatan media pembelajaran IPA, 2) merancang media pembelajaran IPA, dan 3) aktivitas membuat media pembelajaran IPA berbasis lingkungan. Rubrik penilaian produk media pembelajaran IPA berbasis lingkungan dan aktivitas peserta pelatihan menggunakan skala 100 .

Indikator keberhasilan proses pelaksanaan kegiatan pelatihan ini berupa keberhasilan produk berupa media pembelajaran yang dihasilkan peserta pelatihan minimal kategori baik dan skor rata-rata aktivitas minimal termasuk kategori tinggi, dan respon peserta pelatihan terhadap kegiatan pelatihan ini adalah positif. Adapun pedoman yang digunakan dalam penilaian keberhasilan pelaksanaan pelatihan adalah sebagai berikut. 0-39 = sangat kurang, $40-54=$ kurang; 55-69 = cukup ; 70-84 = baik; 85-100 = sangat baik

\section{Hasil Dan Pembahasan}

Kegiatan pelatihan pembuatan media pembelajaran IPA berbasis lingkungan bagi guru-guru MI Negeri dan Swasta di Kabupaten Buleleng telah dilaksanakan pada hari Sabtu, 6 dan 8 Agustus 2016. Kegiatan pelatihan ini bertempat di Ruang Laboratorium Fisika Dasar, Universitas Pendidikan Ganesha yang berlangsung dari pukul 08.00 WITA hingga 16.00 WITA. Telah diundang guru IPA sekolah MI Negeri maupun Swasta di Kabupaten Buleleng sebanyak 34 orang, serta perwakilan dari mahasiswa yang nantinya akan menjadi seorang tenaga pengajar setelah menyelesaikan studinya. Peserta pelatihan keseluruhannya berjumlah 34 orang yang terdiri dari 23 guru-guru IPA sekolah MI di Kabupaten Buleleng dan 11 mahasiswa calon guru.

Peserta pelatihan yang mengikuti pelatihan berasal dari 12 sekolah MI Negeri dan Swasta yang ada di daerah Patas, Kaliasem, Singaraja, Gerokgak, Tegallingah, Pegayaman, Gondol, Seririt, masingmasing sekolah diwakili oleh 2 orang guru IPA. Peserta pelatihan didominasi oleh guru tenaga pengajar 
muda yang berusia 30-35 tahun dan hanya satu orang guru berusia 40-50 tahun dengan status guru PNS, guru tetap yayasan dan guru honor yayasan. Sepuluh (10) guru berijasah pendidikan agama, dua orang guru berijasah teknik komputer, dua orang guru berijasah pendidikan guru SD, dan lainnya berijasah pendidikan matematika, bahasa, dan biologi.

Narasumber dari kegiatan pelatihan ini adalah anggota P2M yaitu Dr. A.A.I.A. Rai Sudiatmika, M.Pd. dan Dewi Oktofa Rachmawati, S.Si., M.Si.. Hari pertama, kegiatan pelatihan ini diawali dengan penyampaian materi peran media pembelajaran oleh Dr. A.A.I.A. Rai Sudiatmika, M.Pd dilanjutkan dengan diskusi. Pertanyaan yang muncul dari peserta pelatihan putar peran media dalam pembelajaran adalah : 1) media pembelajaran yang tepat digunakan untuk menyampaikan pesan pada peserta, 2) kesulitan guru dalam mengelola alokasi waktu jika media pembelajaran selain papan tulis yang digunakan, 3) ketakutan guru dalam menyampaikan pesan dengan menggunakan media, dan 4) kesulitan guru membuat media yang tidak tersedia disekolah yang selalu berubah sesuai tuntutan kurikulum. Nara sumber menekankan pada definisi media pembelajaran, hal-hal yang harus diperhatikan dalam memilih media pembelajaran, manfaat media pembelajaran.

Penyegaran materi IPA (fisika) diberikan oleh Dewi Oktofa Rachmawati, S.Si., M.Si. . Pada sesi ini, guru-guru peserta pelatihan memanfaatkan sesi ini untuk mengklarifikasi konsep yang selama ini mereka pahami. Guru memahami konsep perpindahan kalor secara konveksi pada siswa melalui proses mengamati gelombung-gelembung saat air mendidih. Pada konsep gaya gravitasi bahwa percepatan gravitasi hanya dialami oleh benda yang bergerak. Ketika benda berada dalam suatu zat cair benda akan mengalami gaya gravitasi saja. Pada konsep pesawat sederhana system katrol bahwa jumlah tali menentukan jumlah gaya yang dibutuhkan. Pada tuas, semakin dekat beban ke titik tumpu semakin besar usahanya. Sifat cahaya hanya bergerak lurus, dipantulkan dan dapat menebus benda bening. Guru tidak dapat menunjukkan arah utara selatan Kegiatan selanjutnya, guru-guru mengidentifikasi bahan-bahan dari lingkungan/ bahan recycle yang telah disiapkan oleh panitia untuk digunakan dalam pembuatan media pembelajaran IPA yang relevan dengan konsep yang akan disampaikan. Sebagian guru-guru IPA masih kebingungan untuk memilih bahan yang sesuai dengan media pembelajaran yang akan dibuat. Sebagian besar memilih bahan untuk pembuatan media pembelajaran yang relevan dengan konsep wujud zat dan sifat serta perubahan wujud zat. Pendamping pelatihan membimbing guru-guru untuk memilih bahan untuk pembuatan media pembelajaran yang relevan untuk konsep pesawat sederhana, cahaya, gaya angkat, gaya gesek, listrik dan magnet.

Pelatihan pembuatan media pembelajaran dilatihkan oleh pendamping pelatihan, penilaian proses dilakukan selama pelatihan. Selanjutnya tugas mandiri bagi peserta pelatihan untuk menyelesaikan media pembelajaran IPA yang sudah dirancang. Hari kedua, dilanjutkan guru-guru menampilkan produk media pembelajaran dengan teknik presentasi disertai dengan penilain produk hasil pelatihan. Produk media pembelajaran IPA berbasis lingkungan yang dihasilkan oleh guru dari mulai yang sederhana sampai yang inovatif. Antara lain tuas yang terbuat dari kayu, katrol tetap dari karton dengan penyangganya dari kayu, magnet induksi dari paku dan kawat lilitan, rangkaian seri dan parallel di atas papan dari karton, lup dari bohlam yang diisi air, lup dari es batok kelapa, alat konveksi dari bohlam dan balon, pengganti prisma untuk membuat pelangi dari cermin, baskom dan air, alat menentkan sifat cahaya merambat lurus dari malam, karton, lilin, perubahan zat dari lilin, perubahan energy bunyi menjadi energy gerak dari batok kelapa, balon benang,sendok, piring. gaya angkat dari sebatang bamboo, benang dan balok sebagai beban, rambatan bunyi dalam zat cair dari tabung kaca, sumbat, lonceng dan kayu serta benang dan gas memiliki massa dari gantungan baju benang dan balon tiup.

Respon guru pada hari kedua pelatihan juga sangat positif. Guru peserta pelatihan menyatakan senang hasil produknya dipresentasikan sehingga ada masukan dari kekurangan konsep yang relevan yang akan disampaikan dari media pembelajaran yang dibuat. Guru peserta pelatihan senang terhadap produk media pembelajaran IPA yang dihasilkan karena dapat dijadikan bukti fisik untuk kenaikan pangkat.

Hasil analisis data aktivitas menunjukkan skor rata-rata indikator mengidentifikasi bahan lingkungan sebagai bahan pembuatan media pembelajaran IPA adalah 86,4 skor rata-rata untuk indikator merancang media pembelajaran IPA adalah 84,5 dan skor rata-rata pada indikator membuat media pembelajaran IPA adalah 85,2. Skor rata-rata aktivitas guru pada pelatihan pembuatan media pembelajaran IPA berbasis lingkungan adalah 85,4 berkategori sangat tinggi. Skor rata-rata produk media pembelajaran IPA yang dihasilkan di akhir pelatihan adalah 83,7 berkategori baik dengan deskripsi skor rata-rata pada indicator media pembelajaran menyampaikan pesan pembelajaran yang relevan dan media pembelajaran sederhana, mudah di buat dan inovatif adalah 85,0 dan 82,4. Hasil ini sudah sesuai dengan kriteria keberhasilan kegiatan pelatihan. Peserta pelatihan memberi respon sangat positif terhadap pelaksanaan pelatihan yang dilaksanakan. Adapun saran yang diberikan adalah 1). pelaksanaan pelatihan dilakukan secara kontinu khusunya penyegaran materi IPA. 2). memberikan kesempatan pada guru 
lainnya yang belum terlibat dalam pelatihan ini dengan jumlah peserta pelatihan lebih dari 2 orang., 3 ). perlu dilakukan pelatihan membuat penelitian tindakan kelas dan penyegaran materi olimpiade bagi guru pembina olimpiade.

Kegiatan ini merupakan kegiatan yang pertama kali dilakukan bagi guru IPA khususnya dari Sekolah Madrasah Ibtidaiyah (MI) yang ada di Kabupaten Buleleng. Guru-guru IPA sekolah MI memiliki potensi yang besar untuk mengembangkan pembuatan media pembelajaran IPA lainnya berbasis lingkungan karena bahan yang ada di lingkungan sekitarnya sudah tersedia. Hal ini didukung oleh skor rata-rata produk media pembelajaran IPA yang dihasilkan di akhir pelatihan yaitu 83,7. Interaksi yang terjadi pada guru-guru dalam satu kelompok dari sekolah MI yang berlainan pada pelatihan ini menambah wawasan mereka dalam hal tukar menukar pengalaman pengetahuan, ide pembuatan media pembelajaran sampai pada menerapkan dalam pembelajaran. Namun ada beberapa kelemahan yang muncul pada guru saat presentasi produk media yang dihasilkan adalah 1) langkah-langkah percobaan melebar dari konsep yang akan disampaikan. seperti konsep yang akan disampaikan bahwa gerak benda dipengaruhi oleh gaya gesek. langkah percobaan yang dibuat adalah balok bergerak pada bidang licin dengan kemiringan tertentu kemudian balok diganti bola. Bidang dilapisi karpet dilalui oleh balok dan bola dengan kemiringan yang berubah ketika balok meluncur. 2) pertanyaan- pertanyaan tidak menuntun ke fokus konsep yang akan disampaikan, seperti mengapa hal ini dapat terjadi? Dengan memberikan masukan-masukan dari narasumber setelah presentasi, peserta pelatihan mengetahui kesalahankesalahannya. Walaupun guru peserta pelatihan memiliki latar belakang keilmuan yang berbeda- beda, mereka tetap bersemangat mengikuti pelatihan dan tidak merasa kecil hati. Guru peserta pelatihan memanfaatkan pelatihan ini dengan baik untuk menimba ilmu dan meningkatkan pengetahuannya dalam hal pembuatan media pembelajaran. Aktivitas guru saat diskusi sangat tinggi, banyak pertanyaan yang disampaikan seputar media dan penyegaran materi. Guru-guru dari sekolah MI yang berlainan saling bertukar pengalaman pada kegiatan pelatihan ini. Kerja sama identifikasi bahan, merancang, membuat media antar guru sangat tinggi walaupun mereka baru kenal satu dengan lainnya saat pelatihan. Hal ini sesuai dengan skor rata-rata aktivitas guru pada pelatihan yaitu 85,4. Guru peserta pelatihan yang mengikuti pelatihan adalah guru yang mengampu mata pelajaran IPA di kelas 4, 5 atau 6. Respon yang diberikan peserta pelatihan sangat positif. Peserta pelatihan berharap kegiatan serupa dilaksanakan secara berkelanjutan karena manfaat yang besar mereka dapatkan.

\section{Simpulan Dan Saran}

Berdasarkan rumusan masalah, simpulan dari kegiatan ini adalah media pembelajaran IPA berbasis lingkungan yang dihasilkan oleh guru-guru MI Kabupaten Buleleng setelah mengikuti pelatihan berkategori baik dengan skor rata-rata 83,7 dengan standar deviasi 1,81. Aktivitas guru peserta pelatihan dalam mengidentifikasi bahan lingkungan, merancang dan membuat media pembelajaran IPA berbasis Lingkungan berkategori sangat tinggi dengan skor rata-rata 85,4 dengan standar deviasi 0,96. Respon guru-guru peserta pelatihan selama mengikuti pelatihan sangat positif.

Terkait dengan hasil kegiatan pelatihan guru-guru MI kabupaten Buleleng yang telah dilakukan, beberapa saran yang disampaikan oleh para peserta pelatihan yakni 1) peserta pelatihan meminta adanya kerjasama lembaga lppm dengan kantor agama sehingga pelatihan serupa mereka dilibatkan, 2) pelatihan pembuatan media pembelajaran hendaknya dilakukan secara kontinu sehingga peserta yang belum sempat ikut pada pelatihan kali ini mendapat kesempatan dilain waktu, 3) guru-guru memerlukan pelatihan berupa penyegaran materi IPA yang nantinya dapat meng- up grade pengetahuan mereka dari waktu ke waktu, 4) guru-guru MI memerlukan pelatihan berupa pelatihan penelitian tindakan kelas.

\section{Daftar Pustaka}

Azhar Arsyad, 2007, Media Pembelajaran. Jakarta. PT Raja Grafindo Persada.

Arief S. Sadiman, et al. 2007. Media Pendidikan. Jakarta. PT. Raja Grafindo Persada

2003. Media Pembelajaran. Jakarta. Departemen Pendidikan Nasional Dirjen Pendidikan Dasar dan Menengah Direktorat Tenaga Kependidikan.

Depdiknas. 2006. Model Pembelajaran Terpadu IPA SMP/MTs/SMP LB. Pusat Kurikulum Balitbang Diknas Permendiknas No 22 tahun 2006 tentang Standar Isi, untuk IPA SD/MI dan SMP/MTs. 